\title{
Guantanamo Bay Naval Base
}

National Cancer Institute

\section{Source}

National Cancer Institute. Guantanamo Bay Naval Base. NCI Thesaurus. Code C123756.

A US Navy military base located on Guantanamo Bay in Cuba. 